\title{
Effect of Silicon Amendments in Enhancing Resistance of Rice Plants against Brown Plant Hopper Nilaparvata lugens (Stal.) in Odisha
}

\author{
Subhalaxmi Roy ${ }^{*}$ and Santosh Kumar Panda \\ Department of Entomology, OUAT, India \\ *Corresponding author
}

\section{A B S T R A C T}

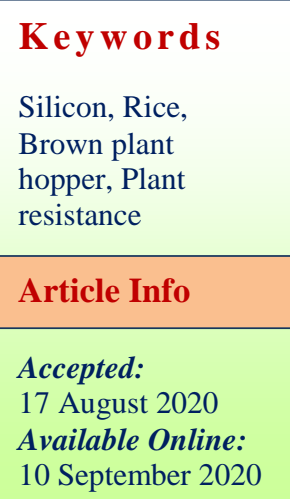

Keywords

Silicon, Rice, Brown plant hopper, Plant

\section{Introduction}

Rice (Oryza sativa L.) is extensively cultivated under the most diverse ecosystems of tropical and sub-tropical regions of the world. With a projected increase in world population to $9-10$ billion by 2050 along with the predicted water scarcity, decrease in arable land and the impending global climate change, it is a great challenge to meet the food requirements of these persons. Among various biotic constraints for rice production, insect pests are of prime importance (Heong and Hardy, 2009). Of over 100 species of insects reported as pests of this crop, 20 are of major economic significance (Prakash et al.,
A field experiment was conducted during kharif 2016 and 2017 in the Central Research Farm of Odisha University of Agriculture and Technology, Bhubaneswar, to evaluate the efficacy of different sources of organic (DAE and DAE, $\mathrm{CaSiO}_{3}$ and RHA respectively at the peak activity of hopper as against 65.59 hoppers/hill in control, exhibiting their supremacy in arresting the pest. However, the performance was at par with that of medium doses indicating the importance of these silicate fertilizers at moderate doses for economic and effective management of $\mathrm{BPH}$ in rice.
2007). The brown planthopper (BPH), Nilaparvata lugens (Stål) (Homoptera: Delphacidae), is a typical phloem sap feeder that has remerged as the treat to rice production in Asia (Normile, 2008; Heong and Hardy, 2009; Prasanna kumar et al., 2013). Rice is a silicon ( $\mathrm{Si}$ ) accumulating plant. Silica is required for healthy and productive development of the rice plant (Yoshida, 1975). Silicon content of monocots is higher than that of dicots. Silicon absorbed by rice from the soil in large amounts that are several fold greater than those of other macronutrients. It is estimated that a rice crop producing a total grain yield of about 5 tonnes $\mathrm{ha}^{-1}$ will normally remove 230 to $470 \mathrm{~kg} \mathrm{Si}$ 
ha $^{-1} \quad\left(500-1000 \quad \mathrm{SiO}_{2} \quad \mathrm{~kg} \mathrm{ha}^{-1}\right)$ from soil (Amarasiri and Perera, 1975). Silicon is absorbed by plants as monosilicic acid $\left[\left(\mathrm{Si}(\mathrm{OH})_{4}\right]\right.$ (Jones and Handreck, 1967). Silicon becomes immobilized and accumulates in plant with tissue age and therefore, young rice leaves may have lower Si concentration and are more susceptible to disease and pests. Extensive cultivation of rice in some regions of Asia and Southeast Asian countries has led to depletion of available silicon (Savant et al., 1997) and warrants the application of silicate fertilizers for achieving sustainable rice yields. The present findings aimed to assess the effect of various doses of silicon in imparting resistance to rice plants against brown plant hopper.

\section{Materials and Methods}

Field experiments was carried out in the Central Agricultural Research Farm of Odisha University of Agriculture and Technology, Bhubaneswar which is situated at $20^{\circ} 15^{\prime} \mathrm{N}$ latitude and $85^{\circ}$ 22' E longitude with an elevation of 25.9 meters above the MSL. Most popular rice variety "Swarna" in 2016 and 2017 was taken in the present field investigation. "Swarna", is a medium duration (140 - 150 days), semi dwarf variety with profuse tillering ability. The field experiments was conducted with 10 treatments comprising diatomaceous earth (DAE) at $0.15,0.3,0.45$ t/ha, calcium silicate $\left(\mathrm{CaSiO}_{3}\right)$ at 2, 3, $4 \mathrm{t} / \mathrm{ha}$ and rice hull ash (RHA) at 2, 3, 4 t/ha along with an untreated control. DAE is an organic source of "Si" is a naturally occurring, soft, siliceous sedimentary rock that is easily crumbled into a fine white to offwhite powder extracted from sea diatoms of American coast containing 80\% -90\% silicon. $\mathrm{CaSiO}_{3}$ is an inorganic source of silicon and commercially available for agricultural use and contain $45 \% \mathrm{Si}$ whereas RHA is organic source, very cheap and available plentily in the locality containing $80-90 \% \mathrm{Si}$. All the sources of silicon are used at their high, medium, and low optimal dose recommended for soil amelioration to study their impact on insect pests of rice such as brown plant hopper in rice. All the treatments were applied as basal dose to rice field during last puddling and much care was taken to avoid mixing effects of inter plot. Random allocation of treatments was done to plots replication wise laid out for the experiment. The field experiment was laid out in Randomized Complete Block Design with ten treatments and three replications and each subplot measured (5m x $4 \mathrm{~m})$.

Observations were recorded from 30DAT to 80 DAT randomly from ten plants from each plot treated with silicon amendments in variety swarna.

\section{Results and Discussion}

Brown pant hopper (BPH) is considered as one of the most serious insect pests of rice in Odisha during both kharif and rabi seasons. Until now farmers are mostly depending on chemical insecticides for its control and because of this, brown plant hopper has developed resistance to most of the commonly used conventional insecticides. Hence, to tackle this pest we need to develop some eco-holistic approaches of which use of silicon may be one. The result thus, obtained on effect of silicon on BPH through field trials during kharif in both the year are presented below.

During kharif trial 2016, observations were taken from 30 DAT to 80 DAT of brown plant hopper infesting the rice crop in the field. At 30 DAT, number of insects per hill was found to be very low ranging from (1.592.77 insects /hill) in all the treatments to (4.27insects /hill in control). From 40 DAT60 DAT the population started increasing 
with (9.11insects /hill) in DAE @0.15t/ha and (14.08 insects /hill) in control observed in 60DAT. At 70 DAT, there was a sudden increase in plant hopper population. Application of resurgence inducing chemical at lower dose of RHA (2.0 t/ha) on 70 DAT, resulted in high pest load subsequently. As a result, at $70 \mathrm{DAT}$, response of $\mathrm{DAE}$ at high dose of $0.45 \mathrm{t} / \mathrm{ha}$ (10.48 insects/hill) followed by $\mathrm{CaSiO}_{3}$ at high dose of $4.0 \mathrm{t} / \mathrm{ha}$ (16.77 insects/hill) and RHA at high dose of $4.0 \mathrm{t} / \mathrm{ha}$ (17.53 insects/hill) caused significant variation in plant hopper population in different treatments. The lowest population of (10.48 insects/hill) was observed in $\mathrm{T}_{3}$ which was at par with $\mathrm{T}_{2}, \mathrm{~T}_{6}$, and $\mathrm{T}_{9}$ treatments. But at 80 DAT, there was a decline in hopper population because of heavy downpour six days after 80 DAT. The hopper population in $\mathrm{T}_{1}$ was the highest (13.97 insects /hill) which was significantly higher from rest of the treatments and was at par over control (15.63 insects /hill).

With respect to mean performance it could be observed that DAE at its highest dose supported (5.10 plant hopper/hill) which was less than the control (17.74 insects /hill).
Among the treatments $\mathrm{CaSiO}_{3}$ at 4.0t/ha harboured least hopper (6.39 insects/hill), followed by RHA at 4.0 t/ha (6.53insects/hill) confirming the decline in level of field resistance to $\mathrm{BPH}$ at higher doses.

During kharif trial 2017, observations were taken from 30 DAT to 80 DAT of brown plant hopper infesting the rice crop in the field. At 30 DAT, number of brown plant hopper per hill was found to be very low ranging from (1.78-2.18 insects /hill in all the treatments to 3.63insects /hill in control). From 40 DAT- 60 DAT the population of brown plant hopper started increasing with (10.83 insects /hill) in RHA at 2.0 t/ha and (16.03 insects /hill) in control in 60DAT. There was a sudden increase in plant hopper population in 70DAT due to application of resurgence inducing chemical at lower dose of DAE at 2.0t/ha on $70 \mathrm{DAT}$, resulted in high pest load subsequently. As a result, at 70 DAT, response of DAE at $0.45 \mathrm{t} / \mathrm{ha}(12.71$ insects/hill) followed by $\mathrm{CaSiO}_{3}$ at $4.0 \mathrm{t} / \mathrm{ha}$ (17.63 insects /hill) and RHA at 3.0t/ha (28.80 insects /hill) caused significant variation in brown plant hopper population in different treatments.

Treatment details

\begin{tabular}{|c|c|c|c|l|}
\hline Treatments no. & Test products & Source & Dose(t/ha) & Place of procurement \\
\hline $\mathbf{T}_{\mathbf{1}}$ & Diatomaceous earth & Organic & 0.15 & Low dose \\
\hline $\mathbf{T}_{\mathbf{2}}$ & Diatomaceous earth & Organic & 0.30 & Medium dose \\
\hline $\mathbf{T}_{\mathbf{3}}$ & Diatomaceous earth & Organic & 0.45 & High dose \\
\hline $\mathbf{T}_{\mathbf{4}}$ & Calcium silicate & Inorganic & 2.0 & Low dose \\
\hline $\mathbf{T}_{\mathbf{5}}$ & Calcium silicate & Inorganic & 3.0 & Medium dose \\
\hline $\mathbf{T}_{\mathbf{6}}$ & Calcium silicate & Inorganic & 4.0 & High dose \\
\hline $\mathbf{T}_{\mathbf{7}}$ & Rice hull ash & Organic & 2.0 & Low dose \\
\hline $\mathbf{T}_{\mathbf{8}}$ & Rice hull ash & Organic & 3.0 & Medium dose \\
\hline $\mathbf{T}_{\mathbf{9}}$ & Rice hull ash & Organic & 4.0 & High dose \\
\hline $\mathbf{T}_{\mathbf{1 0}}$ & Untreated check & & & \\
\hline
\end{tabular}


Table.1 Effect of silicon amendments on Brown plant hopper incidence in rice var. Swarna during kharif' 2016

\begin{tabular}{|c|c|c|c|c|c|c|c|c|c|}
\hline \multirow{2}{*}{$\begin{array}{l}\text { Tr. } \\
\text { No. }\end{array}$} & \multirow[t]{2}{*}{ Treatments } & \multirow{2}{*}{$\begin{array}{l}\text { Dose } \\
\text { (t/ha) }\end{array}$} & \multicolumn{7}{|c|}{ Brown plant hopper population (Nos./hill) in Kharif 2016} \\
\hline & & & 30DAT & 40DAT & 50DAT & 60DAT & 70DAT & 80DAT & MEAN \\
\hline $\mathbf{T}_{1}$ & DAE & 0.15 & 2.77 & 4.46 & 5.08 & 9.11 & 35.06 & 13.97 & 11.74 \\
\hline $\mathbf{T}_{2}$ & DAE & 0.30 & 1.59 & 1.97 & 3.64 & 5.61 & 15.03 & 7.47 & 5.89 \\
\hline $\mathbf{T}_{3}$ & DAE & 0.45 & 1.76 & 2.26 & 3.10 & 6.40 & 10.48 & 6.57 & 5.10 \\
\hline $\mathbf{T}_{4}$ & $\mathrm{CaSiO}_{3}$ & 2.0 & 2.64 & 3.23 & 6.40 & 6.97 & 30.33 & 9.86 & 9.91 \\
\hline $\mathbf{T}_{5}$ & $\mathrm{CaSiO}_{3}$ & 3.0 & 1.82 & 2.37 & 3.83 & 5.52 & 21.84 & 8.27 & 7.28 \\
\hline $\mathbf{T}_{6}$ & $\mathrm{CaSiO}_{3}$ & 4.0 & 1.98 & 2.03 & 4.27 & 5.66 & 16.77 & 7.63 & 6.39 \\
\hline $\mathbf{T}_{7}$ & RHA & 2.0 & 2.75 & 5.57 & 7.30 & 7.37 & 36.36 & 10.68 & 11.67 \\
\hline $\mathbf{T}_{8}$ & RHA & 3.0 & 1.88 & 3.15 & 5.49 & 6.35 & 23.86 & 8.56 & 8.22 \\
\hline $\mathbf{T}_{9}$ & RHA & 4.0 & 1.79 & 3.45 & 4.84 & 5.24 & 17.53 & 6.30 & 6.53 \\
\hline $\mathbf{T}_{10}$ & Control & & 4.27 & 8.47 & 10.08 & 14.08 & 53.89 & 15.63 & 17.74 \\
\hline & $\mathrm{SE}(\mathrm{m}) \pm$ & & 0.354 & 0.678 & 0.620 & 0.637 & 2.250 & 0.668 & \\
\hline & C.D.0.05 & & 1.05 & 2.01 & 1.84 & 1.89 & 6.68 & 1.98 & \\
\hline
\end{tabular}

DAT- Days after treatment

Table.2 Effect of silicon amendments on Brown plant hopper incidence in rice var. Swarna during kharif' 2017

\begin{tabular}{|c|c|c|c|c|c|c|c|c|c|}
\hline Tr. & Treatments & Dose & \multicolumn{7}{|c|}{ Brown plant hopper population (Nos./hill) in Kharif 2017} \\
\hline & & & 30DAT & 40DAT & 50DAT & 60DAT & 70DAT & 80DAT & MEAN \\
\hline $\mathbf{T}_{\mathbf{1}}$ & DAE & 0.15 & 1.97 & 2.17 & 3.56 & 9.35 & 32.99 & 9.80 & 9.97 \\
\hline $\mathbf{T}_{2}$ & DAE & 0.30 & 2.11 & 1.68 & 2.79 & 5.04 & 16.53 & 7.05 & 5.87 \\
\hline $\mathbf{T}_{3}$ & DAE & 0.45 & 1.78 & 2.00 & 1.82 & 4.33 & 12.71 & 5.38 & 4.67 \\
\hline $\mathbf{T}_{4}$ & $\mathrm{CaSiO}_{3}$ & 2.0 & 2.07 & 2.32 & 3.96 & 7.96 & 31.79 & 10.98 & 9.85 \\
\hline $\mathbf{T}_{5}$ & $\mathrm{CaSiO}_{3}$ & 3.0 & 2.13 & 1.39 & 2.16 & 5.55 & 21.73 & 8.48 & 6.91 \\
\hline $\mathbf{T}_{6}$ & $\mathrm{CaSiO}_{3}$ & 4.0 & 2.18 & 1.93 & 2.48 & 4.91 & 17.63 & 9.76 & 6.48 \\
\hline $\mathbf{T}_{7}$ & RHA & 2.0 & 2.05 & 3.67 & 3.67 & 10.83 & 40.34 & 12.93 & 12.25 \\
\hline $\mathbf{T}_{8}$ & RHA & 3.0 & 2.08 & 2.73 & 3.56 & 7.69 & 28.80 & 8.46 & 8.89 \\
\hline $\mathbf{T}_{9}$ & RHA & 4.0 & 1.92 & 1.35 & 2.60 & 5.70 & 31.10 & 10.45 & 8.85 \\
\hline $\mathbf{T}_{10}$ & Control & & 3.63 & 5.82 & 7.65 & 16.03 & 77.29 & 17.88 & 21.38 \\
\hline & $\mathrm{SE}(\mathrm{m}) \pm$ & & 0.466 & 0.617 & 0.686 & 0.814 & 2.260 & 1.131 & \\
\hline & C.D.0.05 & & NS & 1.83 & 2.03 & 2.42 & 6.71 & 3.36 & \\
\hline
\end{tabular}

DAT- Days after treatment 
Table.3 Brown plant hopper incidence pooled data over kharif' 2016 and 2017 as influenced by different sources of silicon in rice var. Swarna

\begin{tabular}{|c|c|c|c|c|c|c|c|c|c|c|c|c|c|c|c|c|c|c|c|}
\hline \multirow{2}{*}{$\begin{array}{l}\text { Tr. } \\
\text { No. }\end{array}$} & \multirow{2}{*}{$\begin{array}{l}\text { Treatment } \\
\text { and dose } \\
\text { (t/ha) }\end{array}$} & \multicolumn{3}{|c|}{ 30DAT } & \multicolumn{3}{|c|}{ 40DAT } & \multicolumn{3}{|c|}{ 50DAT } & \multicolumn{3}{|c|}{ 60DAT } & \multicolumn{3}{|c|}{ 70DAT } & \multicolumn{3}{|c|}{ 80DAT } \\
\hline & & 2016 & 2017 & $\begin{array}{c}\text { Pooled } \\
(2016- \\
\text { 2017) }\end{array}$ & 2016 & 2017 & $\begin{array}{l}\text { Pooled } \\
(2016- \\
\text { 2017) }\end{array}$ & 2016 & 2017 & $\begin{array}{c}\text { Pooled } \\
(2016- \\
\text { 2017) }\end{array}$ & 2016 & 2017 & $\begin{array}{c}\text { Pooled } \\
(2016- \\
\text { 2017) }\end{array}$ & 2016 & 2017 & $\begin{array}{c}\text { Pooled } \\
(2016- \\
\text { 2017) }\end{array}$ & 2016 & 2017 & $\begin{array}{l}\text { Pooled } \\
(2016- \\
\text { 2017) }\end{array}$ \\
\hline $\mathbf{T}_{1}$ & DAE (0.15) & 2.77 & 1.97 & 2.37 & 4.46 & 2.17 & 3.32 & 5.08 & 3.56 & 4.32 & 9.11 & 9.35 & 9.23 & 35.06 & 32.99 & 34.03 & 13.97 & 9.8 & 11.89 \\
\hline $\mathbf{T}_{2}$ & DAE (0.30) & 1.59 & 2.11 & 1.85 & 1.97 & 1.68 & 1.83 & 3.64 & 2.79 & 3.22 & 5.61 & 5.04 & 5.33 & 15.03 & 16.53 & 15.78 & 7.47 & 7.05 & 7.26 \\
\hline $\mathbf{T}_{3}$ & DAE (0.45) & 1.76 & 1.78 & 1.77 & 2.26 & 2.00 & 2.13 & 3.1 & 1.82 & 2.46 & 6.4 & 4.33 & 5.37 & 10.48 & 12.71 & 11.60 & 6.57 & 5.38 & 5.98 \\
\hline $\mathbf{T}_{4}$ & $\begin{array}{l}\mathrm{CaSiO}_{3} \\
(2.0)\end{array}$ & 2.64 & 2.07 & 2.36 & 3.23 & 2.32 & 2.78 & 6.4 & 3.96 & 5.18 & 6.97 & 7.96 & 7.47 & 30.33 & 31.79 & 31.06 & 9.86 & 10.98 & 10.42 \\
\hline $\mathbf{T}_{5}$ & $\begin{array}{l}\mathrm{CaSiO}_{3} \\
(\mathbf{3 . 0})\end{array}$ & 1.82 & 2.13 & 1.98 & 2.37 & 1.39 & 1.88 & 3.83 & 2.16 & 3.00 & 5.52 & 5.55 & 5.54 & 21.84 & 21.73 & 21.79 & 8.27 & 8.48 & 8.38 \\
\hline $\mathbf{T}_{6}$ & $\begin{array}{l}\mathrm{CaSiO}_{3} \\
(4.0)\end{array}$ & 1.98 & 2.18 & 2.08 & 2.03 & 1.93 & 1.98 & 4.27 & 2.48 & 3.38 & 5.66 & 4.91 & 5.29 & 16.77 & 17.63 & 17.20 & 7.63 & 9.76 & 8.70 \\
\hline $\mathbf{T}_{7}$ & RHA (2.0) & 2.74 & 2.05 & 2.40 & 5.57 & 3.67 & 4.62 & 7.3 & 3.67 & 5.49 & 7.37 & 10.83 & 9.10 & 36.36 & 40.34 & 38.35 & 10.68 & 12.93 & 11.81 \\
\hline $\mathbf{T}_{8}$ & RHA (3.0) & 1.88 & 2.08 & 1.98 & 3.15 & 2.73 & 2.94 & 5.49 & 3.56 & 4.53 & 6.35 & 7.69 & 7.02 & 23.86 & 28.80 & 26.33 & 8.56 & 8.46 & 8.51 \\
\hline $\mathbf{T}_{9}$ & RHA (4.0) & 1.79 & 1.92 & 1.86 & 3.45 & 1.35 & 2.40 & 4.84 & 2.6 & 3.72 & 5.24 & 5.7 & 5.47 & 17.53 & 31.10 & 24.32 & 6.3 & 10.45 & 8.38 \\
\hline $\mathbf{T}_{10}$ & Control & 4.27 & 3.63 & 3.95 & 8.47 & 5.82 & 7.15 & 10.08 & 7.65 & 8.87 & 14.08 & 16.03 & 15.06 & 53.89 & 77.29 & 65.59 & 15.63 & 17.88 & 16.76 \\
\hline & $\mathrm{SE}(\mathrm{m}) \pm$ & 0.354 & 0.466 & 0.519 & 0.678 & 0.617 & 0.896 & 0.62 & 0.686 & 0.863 & 0.637 & 0.814 & 0.925 & 2.25 & 2.26 & 3.049 & 0.668 & 1.131 & 1.068 \\
\hline & C.D..$_{0.05}$ & 1.05 & 1.38 & 1.49 & 2.01 & 1.83 & 2.57 & 1.84 & 2.03 & 2.47 & 1.89 & 2.42 & 2.65 & 6.68 & 6.71 & 8.74 & 1.98 & 3.36 & 3.06 \\
\hline
\end{tabular}


The lowest population of (12.71 insects/hill) was observed in $\mathrm{T}_{3}$ which was at par with $\mathrm{T}_{2}$, $\mathrm{T}_{6}$, and $\mathrm{T}_{9}$ treatments. But at $80 \mathrm{DAT}$, there was a decline in hopper population because of heavy rainfall six days after 80 DAT. The hopper population in $\mathrm{T}_{7}$ was the highest (12.93 insects /hill) which was significantly higher than the rest of the treatments but significantly lower than control (17.83 insects /hill). With respect to mean performance it could be observed that RHA at its lower dose supported 12.25 plant hopper/hill which was less than the control (21.38 insects /hill). DAE at 0.45 t/ha showed less incidence of insects (4.67/hill) which was lower than control (21.38/hill) followed by $\mathrm{CaSiO}_{3}$ at $4.0 \mathrm{t} / \mathrm{ha}(6.48 / \mathrm{hill})$, and RHA at $4.0 \mathrm{t}$ /ha $(8.85 /$ hill $)$ confirming the decline in level of field resistance among different silicon treated plants.

\section{Pooled data}

The pooled data of two seasons trial with cv. Swarna presented in (Table 3) revealed that all the $\mathrm{Si}$ treatments showed low infestation of brown plant hopper over control. Supremacy of highest dose of DAE $(0.45 \mathrm{t} / \mathrm{ha})$ with a record of (11.60insects/hill) in 70DAT followed with high dose of $\mathrm{CaSiO}_{3}$ (4.0 t/ha) recorded (17.20insects/hill) and highest dose of RHA (0.45 t/ha) recorded (24.32insects/hill) over control (65.59isects/hill). Similar trend was seen in 80DAT with better results of DAE $(0.45 \mathrm{t} / \mathrm{ha})$ recorded $(5.98 \mathrm{insects} / \mathrm{hill})$ followed with high dose of $\mathrm{CaSiO}_{3}$ (4.0 t/ha) recorded (8.70 insects/hill) and highest dose of RHA (0.45 t/ha) recorded (8.38 insects/hill) over control (16.76 insects/hill).

Field experiments have been conducted with cultivar 'Swarna' in kharif in 2016-2017. Rice cultivar 'Swarna' is the most popular variety amongst the rice growers of the state and widely cultivated in kharif season. The variety is popular because of its grain quality and yield potentiality. However, this cultivar is moderately susceptible to major insect pests and diseases and hence, suitable for the entomological experiments. Brown plant hopper infestation was recorded at highest peak activity in both the season. In kharif season 2016 lowest incidence in DAE at $0.45 \mathrm{t} / \mathrm{ha}$ (10.48insects/hill) was recorded in cv. Swarna followed with casio $_{3}$ at 4.0t/ha (16.77insects/hill) and RHA at 4.0t/ha (17.53insects/hill) as against (53.89insects/hill) in control in table 1. In kharif season 2017 lowest incidence in DAE at $0.45 \mathrm{t} / \mathrm{ha}$ (12.71insects/hill) was recorded in cv. Swarna followed with $\mathrm{CaSiO}_{3}$ at 4.0t/ha (17.63 insects/hill) and RHA at 3.0t/ha (28.80 insects/hill) as against (77.29 insects/hill) in control in table 2.

Silicon amendments at various doses showed significant effects in arresting the plant hopper damage compared to that of control. The efficacy however, differed from source to source and dose to dose. Over seasons DAE at (0.45 t/ha) along with $\mathrm{CaSiO}_{3}$ at (4.0 t/ha) and RHA at (4.0 t/ha) demonstrated their supremacy in restricting the brown plant hopper damage.

Rice has been reported to be one of the several typical $\mathrm{Si}$ accumulating plant species and $\mathrm{Si}$ accumulation in rice was proved to be an active process (Ma et al., 2006). For BPH, reduced performance was recorded on rice plants treated hydroponically with high $\mathrm{Si}$ concentrations ( $\mathrm{He}$ et al., 2015). A recent report determined that $\mathrm{Si}$ amendment impaired feeding behaviors and reduced the feeding amount and population growth in BPH (Yang et al., 2017). It appears that silicon defence against insects is either due to enhanced physical protection for attack or plant parts of being a low quality because $\mathrm{Si}$ deposition makes it less digestible. Silicon content regulation of biochemical pathways may also play a role in inducing resistance (Van Bockhaven et al., 2013). The present findings support the hypothesis that $\mathrm{Si}$ amendments through different sources (Table 1 and 2) restricting the brown plant hopper damage to rice plants. In the present study, plants receiving higher doses of DAE, $\mathrm{CaSiO}_{3}$ and RHA showed low infestation and damage to the plant. 


\section{Acknowledgement}

The authors are very much thankful to Dr. S.K. Pattnaik, Ex- Professor and head, Dept of Soil science and Agricultural Chemistry, College of Agriculture, Odisha University of Agriculture and Technology for helping in successful research of silicon amendments in field trial conducted in kharif season.

\section{References}

Aarekar SA, Pawar RB, Kulkarni RV, Pharande AL. 2014. Effect of silicon on yield, nutrients uptake by paddy plant and soil properties. J Agri. Res. Tech. 39(2):328331.

He, W., Yang, M., Li, Z., Qiu, J., Liu, F., Qu, X., Li, R. 2015. High levels of silicon provided as a nutrient in hydroponic culture enhances rice plant resistance to brown planthopper. Crop Protection, 67, 20-25. https:// doi.org/10.1016/j.cropro.2014.09.013

Heong K L, Hardy B. 2009. Planthoppers: New Threats to the Sustainability of Intensive Rice Production Systems in Asia. Los Baños, the Philippines: International Rice Research Institute: 1-470.

Horgan F. 2009. Mechanisms of resistance: a major gap in understanding planthopperrice interactions. In: Heong $\mathrm{K}$ L, Hardy $\mathrm{B}$. Planthoppers. New Threats to the Sustainability of Intensive Rice Production Systems in Asia. Los Baños, the Philippines: International Rice Research Institute. Pp. 281-302.

Jones LHP, Handreck KA.1967. Silica in soils, plants and animals. Adv. Agron. 19: 107149.
Ma JF and Yamaji N. 2006. Silicon uptake and accumulation in higher plants, Trends in Plant science, 11(8): 392-397.

Normile D. 2008. Reinventing rice to feed the world. Science, 321: 330-333.

Prakash A, Rao J, Singh O N, Tyagi J P, Singh S, Rath P C. 2007. Rice: the Queen of Cereals. Cuttack, India: Applied Zoologist Research Association Publication. Pp. 1215.

Prasannakumar N R, Chander S, Sahoo R N, Gupta V K. 2013. Assessment of brown planthopper, Nilaparvata lugens (Stål.), damage in rice using hyperspectral remote sensing. Int J Pest Manage, 59(3): 180188.

Savant NK, Datnoff LE, Snyder GH.1997. Depletion of plant available silicon in soils: A possible cause of declining rice yields. Commun. Soil Sci. Plant Anal; 28: 1245-1252.

Van Bockhaven J, De Vleesschauwer D, and Hofte M. 2013. Towards establishing broad-spectrum disease resistance in plants: silicon leads the way, Journal of Experimental Botany, 64, 1281-1293.

Yang, L., Han, Y., Li, P., Wen, L., and Hou, M. 2017. Silicon amendment to rice plants impairs sucking behaviors and population growth in the phloem feeder Nilaparvata lugens (Hemiptera: Delphacidae). Scientific Reports, 7, 1101. https://doi.org/10.1038/s41598-01701060-4

Yoshida S. 1975. The physiology of silicon in rice. Tech. Bull. No. 25. Food and Fertilizer Technical Centre, Taipei, Taiwan. 27.

\section{How to cite this article:}

Subhalaxmi Roy and Santosh Kumar Panda. 2020. Effect of Silicon Amendments in Enhancing Resistance of Rice Plants against Brown Plant Hopper Nilaparvata lugens (Stal.) in Odisha. Int.J.Curr.Microbiol.App.Sci. 9(09): 2171-2177. doi: https://doi.org/10.20546/ijcmas.2020.909.272 